This is a self-archived version of an original article. This version may differ from the original in pagination and typographic details.

Author(s): Toivanen, Juhana; Pereira da Silva, José Filipe

Title: The Active Nature of the Soul in Sense Perception: Robert Kilwardby and Peter Olivi

Year: 2010

Version: Accepted version (Final draft)

Copyright: @ B Bill, 2010.

Rights: In Copyright

Rights url: http://rightsstatements.org/page/InC/1.0/?language=en

Please cite the original version:

Toivanen, J., \& Pereira da Silva, J. F. (2010). The Active Nature of the Soul in Sense Perception: Robert Kilwardby and Peter Olivi. Vivarium, 48, 245-278.

https://doi.org/10.1163/156853410x535824 
This is an electronic version of an article published in Vivarium 48 (2010): 245-278.

The original article can be accessed at:

http://brill.publisher. ingentaconnect.com/content/brill/viv/2010/00000048/F0020003/art00001

\title{
The Active Nature of the Soul in Sense Perception: Robert Kilwardby and Peter Olivi
}

\author{
J.F. Silva \& J. Toivanen \\ filpas.mail@gmail.com \& juhana.toivanen@jyu.fi \\ University of Jyväskylä \& University of Jyväskylä/EHESS, Paris
}

Vivarium 48 (2010): 245-278.

CBrill 2010 


\begin{abstract}
This article discusses the theories of perception of Robert Kilwardby and Peter of John Olivi. Our aim is to show how in challenging certain assumptions of medieval Aristotelian theories of perception they drew on Augustine and argued for the active nature of the soul in sense perception. For both Kilwardby and Olivi, the soul is not passive with respect to perceived objects; rather, it causes its own cognitive acts with respect to external objects and thus allows the subject to perceive them. We also show that Kilwardby and Olivi differ substantially regarding where the activity of the soul is directed to and the role of the sensible species in the process, and we demonstrate that there are similarities between their ideas of intentionality and the attention of the soul towards the corporeal world.
\end{abstract}

Keywords: Robert Kilwardby, Peter of John Olivi, perception, soul, species, intentionality, attention, history of philosophy, medieval philosophy

\title{
1 Introduction
}

When Aristotelian natural philosophy began to be taken up in the medieval Latin West, it challenged traditional accounts of the soul, its nature, and its relation to the body. From this development there arose discussions concerning the powers of the soul, their operations, and their relations to the soul itself. Aristotelian philosophy was not, however, accepted uncritically and without philosophical reflection on its presumptions and consequences. Many thirteenth-century authors considered Aristotle's positions more or less problematic, and they ended up rejecting some aspects of them. /246/

One particular case in which Aristotle's view was widely but not universally accepted is sense perception. Aristotle explains perception in accordance with his general theory of change. ${ }^{1}$ He understands perception as a causal relation between the perceived object and the power of the soul. It is a passive process, in the sense that the organs and the powers of the senses are acted upon by perceptible objects. The objects are in actuality what the powers of the senses are (merely) in potentiality, and perception takes place when an external object actualizes first the medium between

\footnotetext{
${ }^{1}$ A more detailed presentation of Aristotle's (and Augustine's) theory of sense perception and the variety of medieval interpretations of it is beyond the scope of the present article. Our aim here is to present only the aspects that are relevant in order to understand Kilwardby's and Olivi's positions.
} 
the object and the sense organ and then, through the medium, the sense power. $^{2}$

Later Aristotelians accepted the idea that senses are passive powers which are actualized from without. They accounted for the causal link between the object and the powers of the soul by appealing to visual images, forms, or-especially after the works of Robert Grosseteste and Roger Bacon-sensible or visual species (species sensibiles) that issue from the object and reach the sense organ, thus enabling the subject to perceive the object. ${ }^{3}$ There were also various ways to account for the nature of the change that the reception of images or species causes in the organs and in the powers of the soul. However, these differences in details did not change the Aristotelian authors' understanding of perception as a passive process.

This Aristotelian approach did not receive universal acceptance. There were authors who rejected the idea of perception as a passive process on philosophical grounds. In the present article we shall explore ideas from two of /247/ them, namely, Robert Kilwardby (ca. 1215-79) and Peter of John Olivi (ca. 1248-98). They both knew Aristotle's thought well, but rather than accepting his view, these two authors shared the view that perception is not the passive reception of external stimuli but a process in which the soul actively brings about its acts of cognition. Perceiving is not something the subject undergoes; it is something he or she does. It is not apparent whether Olivi has read Kilwardby, but they both ground their views on the same Augustinian ideas-such as the ontological superiority of the soul, and the soul's attentive nature with respect to the body and/or the external world. Thus, even though their theories are different, they contain certain similarities as well. By discussing two different versions of the active theory of perception we wish to show first of all that there was

\footnotetext{
${ }^{2}$ See, e.g., Aristotle, De anima II.5, 418a3-6 \& II.12. For discussion, see, e.g., Essays on Aristotle's De anima, eds. Martha Nussbaum \& Amélie Rorty (Oxford, 1995); Stephen Everson, Aristotle on Perception (Oxford, 1997).

${ }^{3} \mathrm{~A}$ good description of the passive nature of the soul and of the metaphysical presuppositions can be found in Simo Knuuttila, 'Aristotle's Theory of Perception and Medieval Aristotelianism', in Theories of Perception in Medieval and Early Modern Philosophy, ed. S. Knuuttila \& P. Kärkkäinen (Dordrecht, 2008), especially pp. 2-6. See aslo Dominik Perler, 'Things in the Mind. Fourteenth-Century Controversies over 'Intelligible Species', $V i$ varium 34:2 (1996), 231-253; Leen Spruit, Species intelligibilis: From Perception to Knowledge. Vol. 1, Classical Roots and Medieval Discussions (Leiden, 1994), 1-255; David C. Lindberg, 'Alhazen's Theory of Vision and Its Reception in the West', Isis 58:3 (1967), 321-341; A. Mark Smith, 'Getting the Big Picture in Perspectivist Optics', Isis 72:4 (1981), 568-589. Both Lindberg and Smith argue for the influence of Alhazen's De aspectibus, especially on Bacon and the later perspectivists, such as John Pecham.
} 
an alternative to the Aristotelian approach, and further that-despite the fact that their philosophical starting point and the sources of inspiration were the same- these two thinkers distanced themselves from Augustine and from one another.

We shall begin by taking up certain features of Augustine's thought, aspects that are central to Kilwardby's and Olivi's theories. Then, in section three, we shall lay out Kilwardby's view, paying special attention to the nature of species and the ontological commitments which justify his theory of the active nature of the soul in sense perception. In section four, we shall turn to Olivi, seeking to show that although he does not accept Augustine's theory of perception, the Augustinian ideas concerning the ontological superiority of the soul and the active nature of perception are central both for his criticism of earlier theories and for his own view. Finally, we shall discuss Olivi's understanding of intentionality and attention and argue that there are similarities between his idea and Kilwardby's account of the soul's relation to the body. 4

\section{The Augustinian Background}

At the time when Kilwardby and Olivi developed their views on sense perception, discussions on the matter were heavily influenced by Aristotle's natural philosophy and also by Arab innovations that had been transmitted to Latin philosophy during the preceding two centuries. Although there was great variety in the theories of perception proposed in these discussions, there were certain general ideas or starting points which were commonly adopted. One /248/ of the most important of these ideas was the passivity of the powers of the soul in the process of perception. Both Aristotelian thinkers and the perspectivists depicted perception as the cognitive powers of the soul "being acted upon" by external objects.

In addition to the approach emphasizing the passivity of sense perception, medieval authors had access to a different tradition in which the soul was regarded as being active when it perceives. Boethius, too, criticized the idea of the passive nature of sense perception, ${ }^{5}$ but Augustine was the most important author to transmit the Neoplatonic conception of the active nature of the soul to the Middle Ages. It is common knowledge that Augustine did not present a systematic account of sense perception ${ }^{6}$. Sev-

\footnotetext{
${ }^{4}$ In the following, José Filipe Silva is primarily responsible for the section concerning Kilwardby, Juhana Toivanen for the section on Olivi.

${ }^{5}$ Boethius, Philosophiae consolatio, ed. L. Bieler (Turnhout, 1984), v, metr. 4; and pros. 5.

${ }^{6}$ Medieval philosophers were aware of this fact. See, e.g., Robert Pasnau, Theories of
} 
eral of his works, especially De Genesi ad litteram, De trinitate, De quantitate animae, and De musica, offer explanations of how we come to know exterior objects, but, apart from terminological issues, it is difficult to see how all those explanations come together to formulate a coherent and detailed account. ${ }^{7}$ In some contexts Augustine seems to suggest an extramissive theory, according to which seeing takes place by a visual ray that issues from the eyes and travels all the way to the perceived object, ${ }^{8}$ but his other ideas do not fit with this view.

Despite the inconsistency of Augustine's ideas, Kilwardby and Olivi took certain principles from his works as starting points for their own theories. They considered the ontological superiority of the soul with respect to corporeal objects to be central to Augustine's theory of sense perception. ${ }^{9}$ According to Augustine's Neoplatonic ontology, spiritual entities are superior to corporeal objects. The soul in itself is a spiritual entity, which is capable of existing without the body. It animates the body and provides it with psychological functions but remains ontologically distinct from it. ${ }^{10} / 249 /$

Due to this ontological superiority of the soul, perceptual acts cannot be understood as the result of an external object acting upon the soul. Augustine sees the capability to act upon something as a sign of superiority, and to be acted upon is a sign of inferiority. Thus, when we perceive, an external object does not impress its image upon the soul. Instead, the soul makes the images of external objects from itself (de semetipsa) and in itself (in semetipsa). ${ }^{11}$ The soul is active in sense perception.

Another key aspect is Augustine's definition of sensation as "a bodily change (passio corporis) that does not go unnoticed by the soul". ${ }^{12}$ It is not easy to understand what exactly Augustine means by this expression. His idea seems to be that external objects cause changes in the sense organs, and when the soul pays attention to these changes, it reacts by forming in

Cognition in the Later Middle-Ages (Cambridge, 1997), 131.

${ }^{7}$ See M.A.I. Gannon, 'The Active Theory of Sensation in St. Augustine', The New Scholasticism 30 (1956), 154-80. See also Gerard O’Daily, Augustine's Philosophy of Mind (London, 1987). The history of the theory of active perception from Augustine to early fourteenth century is a work in progress by J.F. Silva.

${ }^{8}$ See, e.g., Augustine, De trinitate (hereafter trin.) 9.3; De quantitate animae (hereafter an. quant.) 23.43 .

${ }^{9}$ Augustine, De Genesi ad litteram (hereafter Gn. litt.) 12.16.33; an. quant. 30.59; Gn. litt. 7.19.25.

${ }^{10} \mathrm{O}$ 'Daily, Augustine's Philosophy of Mind, 7-79.

${ }^{11}$ trin. 10.5.7; Gn. litt. 12.16.33.

12 “...] sensus sit passio corporis per seipsam non latens animam." (an. quant. 25.48, PL 32, col. 1063). See also an. quant. 23.41; Augustine, De musica (hereafter mus.) 6.5.9-12. 
itself images of the external objects and thus perceives them ${ }^{13}$. Although Augustine does not give a detailed explanation for the ability to perceive external object via their effects on the body, it is clear that he defines perception as an activity of the soul and not just a passive reception of external stimuli. He maintains the commonsensical view that perception presupposes influence from without, but perception does not amount to being affected by external objects. The soul has to pay attention and to actively cause its cognitive acts. This passage becomes important in thirteenthcentury discussions. What to make of it is a matter of disagreement between our two authors. Whereas for Kilwardby perception consists of a reaction to an affection (affectio) in the body and of the soul's awareness of that reaction, Olivi rejects Augustine's definition because it leads, in his view, to the epistemological problems of representationalism.

\section{Kilwardby's Theory of Sense Perception}

Kilwardby discusses human cognition in several of his works, but the more detailed account of sense perception is found in a work written around 1250, De spiritu fantastico (hereafter DSF). In this work, Kilwardby explains the perceptual process in terms of physiological and psychological elements, with /250/ special explanatory value to be given to the latter. The sensory soul is divided into sensitive power (further divided into common and proper senses $)^{14}$, which operates in the presence of the object, and imaginative power, which operates in its absence. The central focus of Kilwardby's theory of sense perception is to explain how image of the object in the sensory soul follows the species received in the sense organ in such a way as to offer an account which accommodates the doctrines of both Aristotle and Augustine on the matter. ${ }^{15}$

The attempt of conciliation is not original with Kilwardby, even though his acknowledgement of the different nature of the Aristotelian and Augustinian accounts of sense perception and the systematic presentation of

\footnotetext{
${ }^{13}$ For discussion concerning Augustine's idea of paying attention, see Deborah Brown, 'Augustine and Descartes on the Function of Attention in Perceptual Awareness', in Consciousness: From Perception to Reflection in the History of Philosophy, ed. S. Heinämaa, V. Lähteenmäki, P. Remes (Dordrecht, 2007), 153-75.

${ }^{14}$ DSF 141. Whereas each of the proper senses knows "the individual sensible things appropriate to it" (DSF 154), the common sense is responsible for the reception (or apprehension) and judgment of all individual sensible things while they are present (DSF 280).

${ }^{15}$ The sense organ includes the whole physiological system, i.e., corporeal spirits (vital and animal), brain ventricles, etc (DSF 173).
} 
arguments for and against both accounts is of some relevance. But the insight of Kilwardby's contribution is the emphasis he places on the activity of the soul with respect to sensible objects exclusively from the viewpoint of the sensory soul, that is, without the interference of the intellective soul. ${ }^{16}$ Now, whereas the sources and the conciliatory tone of Kilwardby's theory ${ }^{17}$ as well as the description of the process have been the subject of other studies, ${ }^{18}$ the present text deals with these issues only insofar as they are necessary for our intended purpose: to shed some light on what the activity of the soul amounts to, on its philosophical justification, and on some of the difficulties arising from such a theory./251/

The Aristotelian aspect of Kilwardby's theory, which he explicitly acknowledges, is the dependency of our knowledge of material objects on the sensible species that are issued forth from the sensible objects and arrive at the senses, ${ }^{19}$ since the sensory soul is empty of images prior to the use of the senses. The sensible object generates from itself a likeness (similitudo), or species, or image (ymago), or form ${ }^{20}$, which first moves the medium and then the sense organ in such a way that it makes itself known

\footnotetext{
${ }^{16}$ See, e.g., DSF 109. This exclusion can only be fully understood in face of Kilwardby's pluralism of the human soul. For a detailed discussion, see J.F. Silva, The Human Soul in Robert Kilwardby's Natural Philosophy and Theology (Unpublished PhD dissertation, University of Porto, 2009). As Z. Kuksewicz's article makes clear, the conciliation was attempted mostly with respect to the intellect ('Criticisms of Aristotelian Psychology and the Augustinian-Aristotelian Synthesis', in The Cambridge History of Later Medieval Philosophy: From the Rediscovery of Aristotle to the Disintegration of Scholasticism, 1100-1600, ed. N. Kretzmann et al. (Cambridge, 1982), 623-628).

${ }^{17}$ P.O. Lewry, 'Robert Kilwardby on Imagination: The Reconciliation of Aristotle and Augustine', Medioevo 9 (1983), 1-42.

${ }^{18}$ J.F. Silva, 'Robert Kilwardby on Sense Perception', in Theories of Perception in Medieval and Early Modern Philosophy, ed. S. Knuuttila \& P. Kärkkäinen (Dordrecht, 2008), 87-99. See also J.R. Veenstra, 'The Subtle Knot. Robert Kilwardby and Gianfrancesco Pico on the Imagination', in Imagination in the Later Middle Ages and Early Modern Times, ed. L. Nauta \& D. Pätzold (Leuven, 2004), 1-20.

${ }^{19}$ DSF 76. DSF 31; 43 (in both places Kilwardby refers to Augustine's Gn. litt. 12.11). See also Robert Kilwardby, De ortu scientiarum, ed. A. Judy (Oxford: Oxford University Press for the British Academy, 1976), chapter IV, §7, 11. Only material objects "can be brought into the senses." (DSF 35, translated by A. Broadie in Robert Kilwardby O.P., On Time and Imagination (Oxford, 1993), (hereafter OI) 35, 79.) All translations of DSF are by Broadie, with emendations in italics by J.F. Silva.

${ }^{20}$ Kilwardby identifies them (see, e.g., DSF 4) as does Roger Bacon, De multiplicatione specierum, ed. D.C. Lindberg, in Roger Bacon's Philosophy of Nature. A Critical Edition, with English Translation, Introduction, and Notes, of De multiplicatione specierum and De speculis comburentibus (Oxford, 1983), I.1, 2, lines 23-26. We shall not examine here the nature of the species.
} 
by making "its likeness present to the knower". ${ }^{21}$ For Kilwardby there must be a change in the sense organ (DSF 123-24), as he explicitly denies the Augustinian extramission theory of the visual rays ${ }^{22}$. Moreover, Kilwardby objects to the view of those to whom the role of the species is to excite the soul; such a view, which he attributes to Boethius even though his target is most likely Richard Fishacre, seems to have become a trend in medieval Augustinian philosophical psychology, especially after Fishacre and William of Auvergne. ${ }^{23}$ /252/

\section{Kilwardby on Augustine versus Aristotle}

Having accepted the Aristotelian principle that all our knowledge of sensible objects must come from sense experience, Kilwardby faces the claim, made by the Aristotelians (Aristotelici), that the action of the object is not limited to the medium and the sense organs but includes also the sensory soul:

[S]ensible things themselves first change the medium, then the sense organ, thirdly the soul itself or the sensory power. For [the sensory thing] makes an impression of its likeness continuously right through the media up to the soul itself [...] Assuming this, it should be said that it is not absurd that the mind or soul should be moved by the organ or the sensible thing because the sensory soul is in potency to the sensible species, and the organ and the soul have that species in the act. And that act has a natural potential towards the fulfilment of that potential. Perhaps Aristotelians would say this, for to judge

21 “[... ] per sui similitudinem presentem cognoscenti." (OI 4, 72; DSF 4, 56.)

${ }^{22}$ DSF 172-175. For Kilwardby, Augustine's extramission theory should be understood as meaning only that the corporeal spirit, which is somehow luminous, is present in the eyes. The same theory is refuted in Quaestiones in Librum Primum Sententiarum, edited by J. Schneider (Munich, 1986), (hereafter QLIS), 89, 278.22-3. In DSF 213, Kilwardby argues that only cats are endowed with the power to illuminate the medium.

${ }^{23}$ DSF 20-22. For William, see De universo, in Opera omnia, ed. F. Hotot, with Supplementum by Blaise Le Feron (Orléans-Paris, 1674; reprinted Frankfurt am Main, 1963), vol. 1, 929-930; J.-B. Brenet, 'Introduction', in Guillaume d'Auvergne. De l'Âme (VII.1-9) (Paris, 1998), 23. The existence of such a view is also acknowledged in John Pecham, Tractatus de anima, ed. G. Melani (Florence, 1948), c. III, 10; Matthew of Aquasparta, Quaestiones disputatae de fide et de cognitione (Florence), q. III, 259-67, and Peter of John Olivi (see below), among others. The identification with Fishacre follows from the similarities of Kilwardby's objection in DSF 11-that it would lead to an unnecessary duplication of images, and to the admission of innate images of sensible objects-and his criticism of the double memory in QLIS 59-62. See footnote 41 below. 
from those of his writings which have reached us he does not seem to have thought differently. ${ }^{24}$

According to these Aristotelians, the exterior object is responsible for causally moving the soul, and sense perception is the result of the actualization of the sense power by the sense object via the species. ${ }^{25}$ The action of the sensible species is not limited to the sense organ; it impresses itself in the sensitive power (DSF 70 and 78), making the object the cause of our perceptual content. If that is the case, then, it is not compatible with Augustine's account:

If the Philosopher means that some thing radiates from the sensible object and that this [some thing] transits through the sense organ, and is then united with the spirit in such a way that what is bodily acts upon the spirit, and that the species in the spirit is essentially different from [both] the spirit and the thing which emitted it, then they [Aristotle and Augustine] do not seem to agree. ${ }^{26}$

/253/ But there is a way out: to accept that the soul does not have in itself the species of material objects prior to the use of the senses and that the soul only gets to know these objects through the reception of their species in the sense organs does not mean for Kilwardby that the receptivity of the sense organs must be extended to the sensory soul. ${ }^{27}$ Sense organs are passive with respect to the likenesses generated by the object, "by means of which [i.e., likenesses] the sensible things are sensed", ${ }^{28}$ but the soul does

\footnotetext{
24"Posset autem dici ad illam quod spiritus sensitiuus non efficit in se ymagines rerum sensibilium, set potius ipsa sensibilia immutantia primo medium, secundum organum sensitiuum, tercio ipsum spiritum uel potenciam sensitiuam. Facit enim impressionem sue similitudinis continue per omnia media usque in animam ipsam. [...] Et hoc tenendo, diceretur quod non est inconueniens animam uel spiritum moueri ab organo uel sensibili, eo quod spiritus sensitiuus est in potencia ad speciem sensibilem, et organum ac sensibile habent illam in actu. Et iste actus habet ordinacionem naturalem ad complendum illam potenciam. Istud forte dicerent Aristotilici, quia non uidetur ipsum aliter sensisse ex scriptis eius que ad nos hucusque uenerunt." (OI 97, 92; DSF 97, 75.13-26.)

${ }^{25}$ DSF 69, 70.23-30. See also DSF 70, 70.31-33; DSF 112, 79-80.36-02.

${ }^{26}$ "Si autem velit Philosophus quod res aliqua irradietur a sensibili, et haec transeat per organum sensus, et inde uniatur spiritui, tamquam corpus sic agat in spiritum, et species in spiritu sit aliud essentialiter a spiritu et ab extra ei immissum, non videntur concordare." (QLIS 68, 202.125-8; translation by J.F. Silva.)

${ }^{27}$ The being acted upon (passio) "non est nisi impressio similitudinis obiecti in ipso organo facta." (DSF 103, 77.21-2; emphasis added.)

${ }^{28}$ "Set cognicionem sensualem a sensibilibus causari, non uidetur aliud nisi quod species sensibilium, per quas sentiuntur, ingerantur sensibus per ipsa sensibilia." (OI 76, 88; DSF 76, 71.27-29.)
} 
not receive these likenesses or species as a patient receives from an agent. ${ }^{29}$ The being-affected which according to Aristotle and Augustine takes place in perception is a state of the body only, not of the sensory soul, ${ }^{30}$ as the soul cannot be affected by the material object and its species. ${ }^{31}$ There is no action of the body upon the soul but rather an action of the soul, assimilating itself to the affection of the body. ${ }^{32}$

Kilwardby's restriction on the change caused by the object is motivated by a basic ontological commitment according to which the world was created as having a hierarchic ordination; within such creation, inferior and material things, such as bodies, do not act but rather are acted upon by superior and immaterial things, such as souls. If this is so in the macrocosmos (in mundo maiori), it is also the case among human beings (which comprise of a kind of cosmos or world on their own). ${ }^{33}$ Therefore, /254/

in Augustine's view what is inconvenient is not that a soul as having such and such a function should be said to be acted upon by a body, but that a soul qua soul, and qua more excellent than the body by nature, should be said to be acted upon by a body. ${ }^{34}$

Following Augustine, Kilwardby argues that it is impossible for the body, the sense object, and the species ${ }^{35}$ - each of which is lower on the scale

\footnotetext{
29“'Item, in 6 De musica, capitulo I4, ubi declarat quomodo anima non patitur a corpore, set omnino facit in illo et de illo [... Ex hiis omnibus constat Augustinum intedere quod spiritus sensitivus dum sentit non recipit ymagines sensibilium a corpore tanquam patiens ab agente." (DSF 54, 67.6-16.)

${ }^{30}$ DSF $114 ; 118 ; 122$.

${ }^{31}$ DSF 103, 77.34-5. In Quaestiones in Librum Secundum Sententiarum, ed. G. Leibold (Munich, 1992) (hereafter QLIIS), 160, 445.111-2, where he is discussing whether the body can affect the soul, Kilwardby turns to Augustine's mus. 6.5.8 and Gn. litt. 12.16.33 as two authoritative instances where Augustine denies in an absolute manner the possibility of something as spiritual as the soul being affected by something as material as the body. See also QLIIS 162 where he refers to the mus. 6.5.9; 4.7.

32 " [... ] actione animae se ipsam assimulantis passioni factae in corpore, et non actione corporis in animam." (QLIS 68, 203.141-142.)

${ }^{33}$ DSF $56,67-8.28-05$.

34"Non enim inde est incoueniens Augustino, quia spiritus unde talis uel talis officii pati dicatur a corpore, set quia spiritus unde spiritus et unde natura dignior corpore." (OI 52, 83; DSF 52, 66.32-4.)

${ }^{35}$ If a body stands low on the scale of being, the species, as an accident, is even lower on that scale (DSF 60, 68.30-3). With arguments taken mainly from Augustine's Gn. litt. Kilwardby argues that the soul is worthier (prestantior) than the body (DSF 53) in such a way that even the image of the body in the soul is worthier than the body considered in its own substance (DSF 89). The body can act upon the soul by resistance only, and this resistance and difficulty is the source of pain (DSF 120). Cf. mus. 6.5.9.
} 
of being than the soul-to act upon the soul, to go beyond their corporeal nature. ${ }^{36}$ The less noble, i.e., that which is material (the object and its species), cannot bring about as an efficient cause a spiritual (i.e., non corporeal) image of itself in that which is more noble, the soul (DSF 62). Now, if neither the body, nor the object, nor the species can act upon the soul, how can perception be explained?

The sense organ is affected by the species flowing from the sensible object, but contrary to what he takes to be the Aristotelian model, Kilwardby argues that the soul actively reacts to this affection, assimilates itself (assimilat se) to or involves itself (conuoluendo se) with the species received in the sense organ, "makes itself like that organ, and makes in itself an image similar to the one in the organ" (DSF 117). ${ }^{37}$ This image /255/

comes into existence by virtue of the sensory soul embracing, and involving with, the species found in the organ. It is in this way that one should understand the physical doctrine concerning the way sensing occurs, and then Aristotle's doctrine will accord with Augustine's. ${ }^{38}$

Augustine is right in asserting that the image of a sensible object in the soul is not the result of the action of the sensible object bringing about its likeness but rather of the soul's motion running counter to the effect on the body, which is brought about by the sensory stimulus. ${ }^{39}$ Motion must here be understood as the process which leads to the image (i.e., the process by

\footnotetext{
36"Actio sensibilis uel ymaginis eius non ascendit ultra limites corporalis nature." (DSF 103, 34-35.) See also DSF 47, where Kilwardby refers to Gn. litt. 12.16. This excerpt is followed by a series of references to other texts of Augustine (namely Gn. litt. 12.20; mus. 6.5 \& 5.9) where the same principle is stated: "These words and similar ones of Augustine clearly intend to show that $a$ body does not impress a sensible image in the sentient spirit." (DSF 50; emphasis added.) There is an impossibility of, as Cees Leijenhorst calls it, "upward causality"; 'Cajetan and Suarez on Agent Sense: Metaphysics and Epistemology in Late Aristotelian Thought", in Forming the Mind: Essays on the Internal Senses and the Mind/Body Problem from Avicenna to the Medical Enlightenment, ed. H. Lagerlund (Berlin, 2007), 238.

${ }^{37}$ DSF 117; see also DSF 103. The image in the soul is not the same as the image in the sense organ: "[...] hic similitudo de similitudine que erat in organo non eadem omnino." (DSF 118, 81.8-9.)

38 "Fit autem ipsa a spiritu sensitiuo complectente et conuoluente secum speciem in organo inuentam. Et sic est intelligenda doctrina phisica de modo sentiendi, et tunc concordabit cum Augustino." (OI 113, 97; DSF 113, 80.12-5.)

39 " $[. .$.$] sentire in corpore non est aliquid pati a corpore, set in eius passionibus attencius$ agere." (OI 54, 83; DSF 54, 67.10-1.) Kilwardby grounds this statement in a passage of the mus. 6.5. See also QLIS 35, 84-5.152-75; and QLIS 68, 203.135-143. The image in the soul is made, not as the result of a 'physical response to exterior impressions', as Veenstra (p. 10) argues, but the spiritual motion of the soul. It is not the animal spirit which assimilates itself to the impressions in the sense organs (see Veenstra, p. 11), but the sensory soul or the incorporeal sensitive spirit, to use Kilwardby's terminology. As Kilwardby makes
} 
which the image comes to be in the soul) or the image itself, as that which is acquired by the process. ${ }^{40}$ The point can be extended thus:

If, however, you wish to have it in the Augustinian way, it can be said that $[\ldots]$ the spirit forms in itself and from itself the image of the exterior thing in the imitation of the image received in the sense [organ]. ${ }^{41}$

/256/ The soul, by conforming itself to the sensible species in the sense organ, makes in and from itself-i.e., by means of its own natural power and out of its substance-the images of sensible things. ${ }^{42}$ The image in the soul is, therefore, nothing but the soul assimilated to the cognizable exterior thing. ${ }^{43}$ At the centre of Kilwardby's theory of sense perception is what one may call the chameleonic capacity of the soul: as with the chameleon (chamaeleo), the colour in the environment is merely the necessary but not the sufficient cause of change; in fact, it is the nature of the chameleon that is the efficient cause of change. ${ }^{44}$ For Kilwardby, the sensible object is the causa sine qua non of sense perception, the necessary condition for the image in the sensory soul to come into existence; ${ }^{45}$ but the efficient cause per se of perception is the sensory soul (DSF 116).

clear, the image is found in the corporeal spirit only because the sensory soul imprints it there in order to motivate the corporeal spirit to carry on its 'orders'.

${ }^{40}$ DSF 150, 90.3-5. See Augustine, mus. 6.11.32, 68-9. On this motion, see DSF 166, 93.29-31; DSF 167, 94.5-7; and De Tempore 65.

41 "Sin autem vis tenere modum Augustini, dici potest quod [...] spiritus in se format et de se imaginem rei forinsecae ad imitationem imaginis receptae in sensu." (Quaestiones in Librum Tertium Sententiarum, Teil 1: Christologie, ed. E. Gössmann (Munich, 1982), (herafter QLIII1S) 44, 189-190.103-7; emphasis added, translation by J.F. Silva). Kilwardby here is reacting to the two theses, probably from Richard Fishacre, that (i) the soul has many species of the same object, some innate, others acquired by sense perception; (ii) the sensible species serve the purpose of exciting the soul to look within itself for the images of sense objects: "[...] ut excitata quodammodo per illas quae in sensu sunt, convertat se super illas intuendas quas in se habet". Fishacre's text (In I Sent., d.3) reads: "Cum ergo species sensibiles veniunt ad cor, excitatur anima per has ad intuendum species intelligibiles in se ipsa"; R. James Long, The Problem of the Soul in Richard Fishacre's Commentary on the Sentences (Unpublished PhD dissertation, University of Toronto, 1968), p. *31. Kilwardby accepts these with respect to the soul of Christ but not the human soul.

42 "[...] spiritus ipse senciens in se formet corporalium et sensibilium ymagines." (DSF 68, 70.15.) See also DSF 134.

${ }^{43}$ DSF $103,77.15-25 ; 125,83.23-6$. See also QLIS 68, 202.109-12.

${ }^{44}$ QLIIS 157, 432.101-3 (however, here Kilwardby says only that the chameleon changes according to the diversitatem colorum quos videt). The image of the chameleon, applied to an explanation of the process of sense perception, is used by Augustine in trin. 11.2.5.

45 "Est autem ymago in organo uel organum ymagine formatum causa sine qua non fieret ymago in spiritu sentiente, set causa eius effectiua non est." (DSF 103, 77.32-34.) "[...] tam cognicio intellectiua quam sensitiua causatur a rebus sensibilibus sicut a causa 
What is particularly important to emphasize is that Kilwardby makes this image-formation the result of the attention (attencio) that the soul devotes to the body. Sense perception is an intentional process, and intentionality, here, is meant to convey the state of the soul as the form and the "ruler" of the body. Intentionality thus means the soul's attentiveness to the body; 46 it expresses not the images' way of being in the soul but the relation of the soul to the body. The soul attends to the affections of the body - which do not pass unnoticed by the soul (DSF 102)—and directs itself towards the sensible objects, which are the cause of those bodily affections, in order to protect the body, which is the instrument of the soul for knowing sensible things (DSF 101). Due to this attention, the soul 'automatically' makes (i.e., without /257/ being aware of itself making) images of every sensory impression affecting the body (DSF 125). Attention is then what makes sense experience possible.

Sensation combines passive and active aspects: there is passivity because sense organs are receptive to sensible species (DSF 57), and there is activity in the soul's assimilacio to the body's passio. ${ }^{47}$ Now, only after the soul finishes making the image, the sensory soul becomes aware of (turns its eye, or pays attention, to) itself assimilated to the species in the sense organ. ${ }^{48}$ Taking the common Aristotelian example of the wax and the seal, Kilwardby argues that

if you place a seal before wax so that it touches it, and you assume the wax has a life by which it turns itself towards the seal and by striking against it comes to be like it, by turning its eye upon itself it sees in itself the image of the seal. ${ }^{49}$

sine qua non fieret, non tamen sicut a causa principaliter et per effectiua cognicionis et informatiua anime, set sicut ab instrumento necessario uel occasione necessaria." (and DSF 123, 82.28-32.) See Veenstra, 'The Subtle Knot', 9; Silva, 'Robert Kilwardby', 93.

${ }^{46}$ See mus. 6.9; Gn. litt. 8.21.42; O'Daly, Augustine's Philosophy of Mind, 44; DSF 119. On intentionality, see Dominik Perler, Théories de l'intentionnalité au moyen âge (Paris, 2003); Richard Sorabji, 'From Aristotle to Brentano: the Development of the Concept of Intentionality', Oxford Studies in Ancient Philosophy. Supplementary Volume, 1991, 227-259. See also Ancient and Medieval Theories of Intentionality, ed. Dominik Perler (Leiden, 2001).

${ }^{47}$ QLIS 68, 203.135-143. See also QLIS 35, 84-5.152-75; mus. VI.5.9-10, 27-31; O'Daly, Augustine's Philosophy of Mind, 84-5; L. Spruit, Species intelligibilis, 180-2; DSF 102, 77.2-3.

${ }^{48}$ DSF 104 . The sensory soul does not, in Kilwardby's view, distinguish between the species in the sense organ and the image in the soul. Kilwardby points out, as does Augustine in trin. 11.3.6, that only reason can distinguish between these two images.

49 “ $[\ldots]$ si posueris sigillum coram cera et ita quod tangat eam, et posueris ceram habere uitam qua se conuertat ad sigillum, et inpingendo in illud assimilet se illi, et in se aciem reflectendo uideat in se ymaginem sigilli." (OI 103, 94; DSF 103, 77.27-8.) See trin. 11.2.3; QLIIS 138, 368-69.173-90. In DSF 116-17, Kilwardby offers a second way to read the 
The contrast with an Aristotelian passive account is clear. In Kilwardby's theory it is as it were the wax which, by pressing itself against the seal, makes itself like the seal. The sensory soul, he continues, sees itself se talem, i.e., as having the image of the object. Kilwardby's reading of the example reveals how he unequivocally attributes the initiative to the sensory soul which presses itself against the seal rather than receiving the motion from outside and, furthermore, that what the soul sees is the image (of the thing) in itself. Although the soul perceives the image (sentitur ymago) it has made in and by itself (DSF 125), and it perceives the external object by means of this image, ${ }^{50}$ the terminus of the intention of the soul (the intencio sentiendi) is neither the image in itself nor the species informing the sense organ, but it is the sensible /258/ thing. ${ }^{51}$ Intentionality, then, also means that the image in the soul is an image of the sensible object, and the intention of the soul is directed to the extra-mental object, not to the image by the means of which the object is perceived.

Kilwardby assumes that for the soul to assimilate itself to (i.e., to make itself like) the species in the sense organ is to assimilate itself to the sensible object (DSF 124); the reasoning seems to be that if the species in the sense organ is a likeness of the sensible object, and the image in the soul is a likeness of the species in the sense organ, then the image in the soul is a likeness of the sensible object. Kilwardby is clearly trying to avoid portraying the image in a strong representationalist sense: what the soul perceives is the object, not the species in the sense organ or itself as such, but itself as having the image of the object.

There is another benefit in such an account: as perception requires, in addition to the soul's attention towards the effects of the body-the soul's turning to itself-the soul does not get confused even in the presence of many stimuli, since

the species of many sensed things may exist simultaneously in one corporeal spirit, though, of them all, only those to which an intention

analogy: it is not the seal itself that is the efficient cause of the image in the wax; rather, that which impresses the seal upon the wax is the efficient cause per se of the image. In the same way, only incidentally is the image in the sense organ the efficient cause of the image in the soul. Rather, the sensory soul is per se the efficient cause of this image coming to be in itself.

50 "Et sic sentit sensibile forinsecum per ymaginem quam in se formauit." (DSF 103, 77.31-2.) See also DSF 104, and especially DSF 110-111.

51 "Set adhuc dices: Si spiritus sentiens primo conuertit aciem in se et deinde in suum organum, quare non dicitur sentire se et organum? Responsio. Quia non conuertit aciem in hec nisi in quantum sunt informata a sensibili, nec in hiis sistit acies, set transit in sensibile; nec in hiis terminatur intencio sentiendi, nec actio ipsa, set sensibile et finis quod extra est. Et ideo illud solum recte dicitur sentiri." (DSF 110-111, 79.21-6.) 
of the soul (intencio animi) directed on some occasion are perceived (apparent). ${ }^{52}$

All the images of the sensory impressions made by the soul are stored in the power of memory (and thus can be present in the corporeal spirit by the action of the sensory soul, not the other way around), but only those images upon which the soul directs its attention are perceived. In the same way, when a human being is asleep, the species flowing from the sense objects continue to impress the sense organs, but these impressions do not cause any acts of $/ 259 /$ perception without the attention of the soul. ${ }^{53}$ They remain for some time in the sense organs and then disappear, just as when we look for a long time at a strong light, the impression remains even after we cease to look at it (DSF 202). The passivity of the sense organ explains the persistence of after-images but not the persistence of those images in the soul (perception includes physiological changes, but it is not limited to these, nor are the physiological changes the cause of the acts of the soul).

What Kilwardby allows himself to say, as he defends the species in medio doctrine, is that the affection of the sense organs and the formation of images are constantly taking place: the body is affected by different species, and the soul continuously reacts to those affections, forming the images of those likenesses that are impressed (in the sense organ). However, it is only sometimes that the soul pays attention to (ergo perceives) some of those images (no reason being given for the perception of some rather than others). The soul forms the image and only then senses it, whether this is done in two successive instants of time or simultaneously, although the formation is naturally prior to the sensing (DSF 125-27). The soul is able to form an image which corresponds to the extra-mental thing because it is naturally endowed with such a capacity (DSF 127; it is, he says, "led by a natural instinct", DSF 128), but it only senses the image once it turns its eye upon itself. But because the soul is not aware of its own motion of reaction (i.e., image formation), Kilwardby strengthens his claim that the external object is an immediate object of perception, whereas the image

\footnotetext{
52 “[...] multorum sensatorum species simul sunt in uno spiritu corporeo, de quibus non apparent nisi illi in quas aliqua occasione dirigitur intencio animi." (OI 203, 123; DSF 203, 104.25-7.) As Cees Leijenhorst remarks, to explain why not all objects affecting the sense organs are perceived was a problem for an Aristotelian theory of sense perception; 'ATTENTION PLEASE! Theories of Selective Attention in Late Aristotelian and Early Modern Philosophy', in Mind, Cognition and Representation. The Tradition of Commentaries on Aristotle's De anima, ed. P.J.J.M. Bakker \& J.M.M.H. Thijssen (Aldershot, 2008), 205.

${ }^{53}$ Moreover, during sleep no image-formation takes place, due to the inactivity of the senses. On sleep and attention, see DSF 268-269.
} 
and the motion through which it is formed are just the means by which the object comes to be in the soul of the perceiver.

However, this explanation gives rise to problems of its own, since it seems to imply that the soul makes images of corporeal objects of which it is not aware and that it is not aware that it makes them. With respect to this latter aspect, the wax-example offers significant evidence: the soul is aware of the object (via species in the sense organ) only by being aware of the image it has made in and by itself. Kilwardby seems to be implying that the sensory soul does not know itself except insofar as it perceives an external object, as it only turns to itself when informed by the image of that object; one may wonder how and why the soul turns its eye to itself, if it is not aware of itself having such an image. Kilwardby himself does not raise the question, and it seems difficult to point out an answer which would convincingly dismiss the problem. /260/

Furthermore, Kilwardby describes how some rather than other images receive the attention of the soul (that is, with the soul turning to those images) but not why the soul selects those images as the targets of its attention. In the only attempt to formulate an explanation, Kilwardby says that it is due to the intensity of one (e.g., ray) above the others. ${ }^{54}$ Kilwardby's expression is plain: "according as the affection of the body is greater or less, the attention of the soul which goes forward to meet the affection will be greater or less". ${ }^{55}$ Now, if the intensity of the reaction is proportional to the intensity of the affection, that is, if the soul reacts differently to a bright light than to a dim one (DSF 100), this seems to assess a causal relation that goes beyond what Kilwardby wishes to admit: the intensity of $X$ seems to be the cause of the soul attending to $X$ rather than $Y$. Kilwardby, however, justifies the proportionality of the reaction with the need of the sensory soul, as the form of the body, to protect and preserve the body it informs. ${ }^{56}$

To conclude, Kilwardby restricts the influence of sensible species to their effect on the sense organs and grants to the active nature of the sensory soul, which attends to the bodily affections, the role of the true cause of perception. ${ }^{57}$ Following Augustine, Kilwardby equates the spirituality

\footnotetext{
${ }^{54}$ DSF 203. In this passage, Kilwardby remarks that of the many rays which reach the eye at a certain moment, one excels over the others in such a way that it outshines the others-which I take to mean that its image is formed, although not necessarily attended to.

55 “ $[\ldots]$ et secundum quod maior uel minor est affectio corporis, erit et maior et minor attencio spiritus occurrentis." (OI 102, 93; DSF 102, 76.35-7.)

${ }^{56}$ DSF 99-101. See also QLIIIIS 46, 216.633-635.

${ }^{57}$ DSF 92. See also DSF 198.
} 
of the soul with its superiority and activity: the soul is active with respect to the body, and the soul's impassibility is grounded on its ontological superiority. In following this approach, Kilwardby sides with a more Augustinian view on sense perception, and his distinction between the soul as the efficient cause per se of perception and the object as the incidental cause might be at the root of Olivi's distinction between the apprehensive powers of the soul as the efficient cause of perception and the object as the terminative cause.

\section{Peter of John Olivi on the Active Nature of Per- ception}

Olivi's theory of perception has been studied to some extent in earlier scholarship. He is known as the first thinker to present a thorough criticism of species theories of perception, which presuppose that the soul is passive with respect / 261 / to external objects in sense perception. His criticism has been shown to stem from both ontological and epistemological problems that he sees in species theories. Moreover, the central ideas that form the basis of his own theory have been discussed in literature. ${ }^{58}$

Yet, as earlier scholarship has almost exclusively depicted Olivi's view as a critical reaction to intramissive species theories-such as those presented by Aquinas and the so-called perspectivists-it has presented a somewhat biased picture of his thought. The similarities between his view and the other proponents of the active nature of the soul in perception have been neglected, and the fact that his criticism is not aimed only at species theories has not been noted with sufficient clarity. Olivi's discussions concerning the ontological and epistemological problems of various kinds of species theories is a part of a larger scale critical engagement with many different types of theories of perception which were defended during the thirteenth century. His criticism comes from two directions. First, he argues that all theories that incorporate sensible species are in fact versions of representationalism, and as such they have to be rejected as inadequate in accounting for cognitive processes. Second, he argues that the soul must be active in perception, and therefore the soul cannot be acted

\footnotetext{
${ }^{58}$ Pasnau, Theories of Cognition, 121-4, 130-4, 168-81; Perler, Théories de l'intentionnalité, 43-75; Spruit, Species Intelligibilis, 215-24; Katherine H. Tachau, Vision and Certitude in the Age of Ockham: Optics, Epistemology and the Foundations of Semantics 1250-1345 (Leiden, 1988), 3-26, 39-54; Juhana Toivanen, Animal Consciousness: Peter Olivi on Cognitive Functions of the Sensitive Soul (Jyväskylä, 2009), 60-73.
} 
upon by objects. The latter aspect of his criticism has been less studied in the literature. It stems ultimately from his understanding of the ontological superiority of the soul, which is closely related to his conception of the freedom of the will and thus theologically loaded, but it has also philosophical consequences.

Coming from these two directions, Olivi ends up rejecting not only species theories but all kinds of views that depict perception as a passive reception of external stimuli. Moreover, his epistemological worries lead him to also criticize Augustinian theories and even to reject Augustine's own definition of perception. Although Olivi accepts Augustine's ideas concerning the ontological superiority and impassibility of the soul ${ }^{59}$ and uses an Augustinian conception of the active nature of the soul to criticize passive theories of /262/ perception, he rejects Augustine's view by appealing to epistemological and phenomenological considerations.

In the rest of the article we shall analyse (i) Olivi's use of Augustinian ideas, (ii) the criticism he aims against earlier theories of perception, and (iii) the reasons why he diverges from the Augustinian view. In this way, we intend to enrich the existing picture of Olivi's theory of cognition. It needs to be noted that we shall not present a thorough analysis of Olivi's own theory because that has been done sufficiently elsewhere. ${ }^{60}$ However, we will (iv) suggest a new interpretation of Olivi's conception of attention which enables the soul to bring about intentional acts of cognition. This interpretation will solve a problem within his theory of perception, which has been pointed out in literature.

By comparing Olivi's view to that of Kilwardby's, we want to argue that despite its originality, the former view is not isolated but grows from a medieval Augustinian tradition of emphasizing the active nature of the soul. However, in certain respects Olivi is more radical than Kilwardby as a defender of the active nature of the soul in sense perception. He rejects the idea that the soul perceives external objects by the bodily changes which they cause. He thinks that the soul must be capable of apprehending external objects directly and immediately, since otherwise it would perceive only internal representations of those objects, and this would lead to epistemological problems of representationalism. The soul intentionally turns itself directly to the external world. In this way, Olivi rejects the Aristotelian scheme more thoroughly than anyone before him by appealing to Augustinian notions. Yet he does not accept Augustine's ideas in

\footnotetext{
${ }^{59}$ Petrus Ioannis Olivi, Quaestiones in secundum librum sententiarum, ed. B. Jansen, Bibliotheca franciscana scholastica medii aevi IV-VI (Florence, 1922-26) (hereafter II Sent.) q. 58, 437-515 (esp. 461-515) and q. 72-4, 1-135.

${ }^{60}$ See note 58 above.
} 
full either, preferring to develop his own view.

\section{The Ontological Superiority of the Soul}

The most extensive discussions concerning sense perception in Olivi's works can be found in questions 58 and 72-4 of the second part of his Summa quaestionum super Sententias. ${ }^{61}$ The ontological superiority of the soul is dealt with especially in questions 72-4, where Olivi discusses the relation between corporeal objects and the spiritual powers of the soul and the efficient causes of cognitive acts. Like Kilwardby, he draws on Augustine, claiming that /263/ corporeal objects cannot act upon the spiritual soul or its powers, since the soul is ontologically superior to the body and to corporeal objects of the external world. ${ }^{62}$ Although he acknowledges that the soul is a form of the body, his view on the relation between the two is far from Aristotelian hylomorphism. The soul is a spiritual entity, one that is composed of so-called spiritual matter that is informed by sensitive and intellectual forms. It is connected to the body because the sensitive form of the soul is a form of the physical body as well, but it still retains a certain level of independence with respect to the body. ${ }^{63}$ Olivi makes a sharp distinction between spiritual beings and corporeal objects, appealing to the distinction between two kinds of matter-the spiritual matter of the soul and the corporeal matter of the body. The soul, being a spiritual entity, is ontologically superior to the body, and this ontological superiority applies to the sensitive powers of the soul (the external and internal senses) as well as to the intellectual powers (the intellect and the will). ${ }^{64}$

The independence of the soul with respect to the body is best seen in Olivi's arguments for the idea that corporeal objects cannot cause changes in the soul and its powers. His arguments are based on the separation of corporeal and extended objects from spiritual and unextended entities-a

\footnotetext{
${ }^{61}$ Question 58 is written between $1277-9$ in Narbonne, and it is explicitly directed against some unnamed Averroists (Averroistae); Sylvain Piron, 'Olivi et les averroïstes', Freiburger Zeitschrift für Philosophie und Theologie, 53-1 (2006), 251-309. According to Sylvain Piron's unpublished dissertation, questions 72-4 date from 1281-2, when Olivi was in Montpellier.

${ }^{62}$ II Sent. q. 72, 15-39.

${ }^{63}$ For discussion on Olivi's conception of the metaphysics of the soul, see Robert Pasnau, 'Olivi on the Metaphysics of Soul', Medieval Philosophy and Theology 6 (1997), 109132; Mikko Yrjönsuuri, 'The Soul as an Entity: Dante, Aquinas, and Olivi', in Forming the Mind, 82-9; V. Mauro, 'La disputa de anima tra Vitale du Four e Pietro di Giovanni Olivi', Studi medievali 38:1 (1997), 89-138.

${ }^{64}$ See, e.g., II Sent. q. 54, 282-3; ibid., q. 58, 461-515.
} 
distinction which reminds one of Descartes' res extensa and res cogitans. ${ }^{65}$ According to Olivi, the cognitive powers and acts of the soul are spiritual and simple:

For, a simple and spiritual act cannot be caused (influxive gigni) by an extended and corporeal species. But all cognitive acts are simple and spiritual. This is clear because [...] every being that is capable of cognition, as such, exceeds infinitely everything that lacks cognition and a power of cognizing. It is clear also from the immediate subject of an act of cognition. As has been said, an act of cognition can primarily and immediately exist only in a simple and spiritual power of the soul. ${ }^{66}$

/264/ Corporeal and extended objects (or species) cannot bring about the acts of the soul because the latter belong to a higher ontological level, which Olivi marks off by using the concepts of simplicity and spirituality. Cognitive acts of the soul require that the powers of the soul be simple and spiritual.

We cannot provide a detailed discussion of these two concepts in this context. However, in order to understand how they are related to Olivi's idea of the ontological superiority of the soul, a few ideas must be clarified. First, Olivi thinks that the simplicity of the soul accounts for the soul's ability to have cognitive acts, even in the case of non-human animals:

Augustine says that the acts are received in the powers of their [viz. brute animals] souls because the organs are not susceptible to these kinds of simple acts or species unless they are informed by simple powers. [...] Since the acts are simple [...] the subject which receives them must have substantial simplicity by which it can be prepared to receive and to sustain them. This is the simplicity of the soul, and its powers, and the simple imposition of the powers to the organs. Thus, insofar as the organs have one simple substantial form and one simple sensitive being, they are capable of having the nature of

${ }^{65}$ Tachau, Vision and Certitude, 46.

66"Quarto, quia actus simplex et spiritualis non potest influxive gigni a specie extensa et corporali. Sed omnis actus cognitivus est simplex et spiritualis. Quod clamat non solum communis ratio cognitionis, quae in tantum est nobilis ut Deo proprie ascribatur et per quam omne cognoscens, in quantum tale, in infinitum excedit omne quod caret cognitione et potentia cognoscendi. Immo etiam clamat hoc eius immediatum subiectum, quia sicut dictum est, non potest primo et immediate esse nisi in simplici et spirituali potentia animae." (II Sent. q. 73, 83-4.) 
a single subject (habere rationem unius subjecti), which is, as it were, simple in relation to the acts, although the organs are extended. ${ }^{67}$

Simplicity in this sense does not mean lack of distinct parts because the soul as a whole is simple, although it is composed of several partial forms and powers. It does not primarily even mean lack of extension, even though the soul and its powers are in themselves unextended. As Olivi puts it, "the soul is not simple by the simplicity of smallness, which is the kind of simplicity of a point [...] Rather, it is simple by a spiritual simplicity, and it has in itself the magnitude of essence, power, and composition of diverse formal natures.". ${ }^{68}$ Unlike a point, which lacks extension but still belongs to the genus of quantity and does not exclude corporeality, ${ }^{69}$ the soul and its powers are simple in a /265/ spiritual way, and the spiritual simplicity distinguishes them from the lower ontological level of corporeal objects.

Spirituality and simplicity often go hand in hand, but Olivi seems to think that neither of them can be reduced to the other. There are simple things, such as points, which are not spiritual, and spiritual things which are not simple - at least not in all the possible senses of simplicity. Olivi uses these concepts to rule out a special ontological class of things. The soul and its cognitive acts have a "simple and spiritual being, that is, an animated, living, and sensitive being" which cannot be attributed to corporeal matter because "to attribute such a kind of being is to elevate corporeal matter to participation in the most united kind of being which transcends all corporeal and extended being. It would give the matter a kind of substantial being that is much higher than some corporeal being."70 It is easy to see that Olivi is distinguishing extended and passive

\footnotetext{
67 “Dicuntur tamen ab Augustino recipi in earum potentiis, quia organa non sunt susceptiva huiusmodi actuum aut specierum simplicium, nisi prout sunt informata ipsis potentiis simplicibus. [...] Quia cum ipsi actus sint simplices [...] oportet quod subiectum in quo recipiuntur habeat aliquam simplicitatem substantialem per quam possit ordinari ad receptionem et sustentationem illarum. Haec autem est simplicitas ipsius animae et potentiarum eius et simplex informatio organorum ab eis. Unde licet ipsa organa sint extensa, prout tamen habent unam formam substantialem simplicem et unum esse sensitivum simplex, possunt habere rationem unius subiecti quasi simplicis respectu ipsorum actuum." (II Sent. q. 58, 512-3.)

68 “Anima non est simplex simplicitate parvitatis, qualis est simplicitas punctalis [...] sed potius est simplex simplicitate spirituali habente in se magnitudinem essentiae et virtutis et compositionem diversarum naturarum formalium."(II Sent. q. 49, 17.)

${ }^{69}$ II Sent. q. 58, 456.

70 “[... ] esse simplex et spirituale, id est, animatum seu vivum et sensitivum; quia dare tale esse est elevare materiam corporalem ad participationem esse unitissimi transcendentis omne esse corporale et extensum, et ideo hoc est dare materiae quoddam esse
} 
matter from living, simple, unextended, and active soul-in a way that comes very close to Descartes' two substances.

Olivi presents philosophical arguments in favour of the spirituality of cognitive acts, but for the most part this is almost a presupposition for him. For instance, when he argues that the cognitive powers of the soul are not passive with respect to external objects, he first presents several arguments to the contrary, and one of the most important of these counter-arguments purports to show that external objects are capable of causing cognitive acts of the soul because they are capable of bringing about simple and spiritual effects. ${ }^{71}$ Olivi rejects this argument, but the fact is that Olivi's own view and the counter-argument concur in their starting point: cognitive acts are simple and spiritual. The same tendency to take this idea as evident is present throughout Olivi's discussion of sense perception. ${ }^{72}$

Because corporeal and extended objects can bring about only corporeal and extended effects, they are incapable of causing anything directly in the soul, and therefore they cannot be efficient causes of cognitive acts. ${ }^{73}$ It is important to note that Olivi does not deny that corporeal objects are capable of bringing about changes in the sense organs. The human (and animal) body is a corporeal object, and therefore there is nothing problematic in the idea that external /266/ objects cause changes in it. For instance, Olivi explains the fact that looking at the sun too long destroys our eyes by appealing to corporeal changes that the sun causes in the eyes, and he seems to allow for other kinds of influences as well. ${ }^{74}$ What Olivi denies is that the bodily changes that external objects bring about in the sense organs would amount to perception. The soul's cognitive activity takes place primarily in the soul and only secondarily in the body: "For a cognitive act is primarily and immediately in the power and not in the organ. This is why it cannot be in the organ in any way unless the organ is informed by the cognitive power by a natural priority."75 The ontological superiority of the soul leads to a certain type of substance dualism, and Olivi's criticism of theories which depict sense perception as a passive process in which the soul is acted upon by external objects is partly based on a dualistic ontology.

substantiale longe altius quam sit aliquod esse corporale." (II Sent. q. 73, 88.)

${ }^{71}$ II Sent. q. 58, 400-3, 437-61.

${ }^{72}$ See, e.g., II Sent. q. 58, 502.

${ }^{73}$ II Sent. q. 58, 437-9, 452-6, 461-515; ibid., q. 72, 18-24; ibid., q. 73, 82-90.

${ }^{74}$ See, e.g., II Sent. q. 58, 480, 484; ibid., q. 61, 582.

75 “Nam actus cognitivus primo et immediatius est in potentia quam in eius organo, unde nec in organo potest aliquo modo esse, nisi sit informatum per ipsam potentiam cognitivam et hoc prius naturaliter." (II Sent. q. 73, 83.) 


\section{Criticism of Earlier Theories of Perception}

Since the soul cannot be acted upon by external objects, it has to be active in its cognitive processes-that is, it has to cause its own acts. From this Augustinian starting point, Olivi tackles different kinds of theories of perception which have as a common feature that they depict perception as a passive process. Then again, part of his criticism is based on epistemological considerations: he thinks that species theories of cognition are incompatible with direct realism and that they lead to problems of representationalism. This line of thinking applies also to certain theories which acknowledge that the soul is active but which explain the process of perception by appealing to sensible species. Because Olivi's criticism stems from these two directions, he rejects certain commonly accepted features of both passive and active theories of perception, and although he is a fierce opponent of species theories of cognition, the species doctrine is only a partial target of his critique. There are three types of theories that he finds problematic, ${ }^{76}$ namely, those that portray the cognitive acts of the soul as being caused by:

(a) external objects,

(b) species which are caused by objects, and

(c) species which are caused by the powers of the soul. /267/

Olivi's criticism of these views appears first in question 58, where his primary intention is to defend the freedom of the will. He notes that many have come to believe that the will is a passive power because they think that all the other powers of the soul are passive. ${ }^{77}$ By contrast, Olivi thinks that the will can be genuinely free only if it is active, which means that it has to be capable of causing its own acts. ${ }^{78}$ In order to defend this idea, Olivi adopts an original strategy: he points out that not only the will but also all the other powers of the soul can be understood as active in this sense. The idea of the active nature of even the sensitive powers of the soul is not original, to be sure. We have already seen that, for instance, Kilwardby argues in its favour. But Olivi differs from Kilwardby as he uses the idea to underscore the freedom of the will.

Theories of the types (a) and (b) depict the soul as passive with respect to external objects: the acts are caused by the objects either directly or by

\footnotetext{
${ }^{76}$ II Sent. q. 58, 461-2.

${ }^{77}$ II Sent. q. 58, 461. See also ibid., q. 74, 124.

${ }^{78}$ Bonnie Kent, Aristotle and the Franciscans: Gerald Odonis' Commentary on the "Nicomachean Ethics" (Ann Arbor: UMI, 1984), 184-205; Mikko Yrjönsuuri, 'Free Will and SelfControl in Peter Olivi', in Emotions and Choice from Boethius to Descartes, ed. H. Lagerlund \& M. Yrjönsuuri (Dordrecht, 2002), 99-128.
} 
the mediation of a species. Olivi rejects these views by appealing to the active nature of the soul in sense perception and by arguing that corporeal objects cannot cause changes in the soul due to the ontological superiority of the soul: "For, a corporeal species, which has location and extension, cannot produce a simple, spiritual, and vital (vivus) act of seeing. But the species which is generated by the object in the organ is corporeal."79

Olivi also points out that the theories of type (b) entail epistemological problems of representationalism, as they postulate intermediary sensible species. He thinks that if perception were mediated by species, the species would be the immediate objects of our perception instead of external objects. He understands species as certain kinds of internal representations of external objects; these representations veil us from actually perceiving external objects. Ultimately this leads to scepticism about the reliability of our cognitive capacities. ${ }^{80}$

Whereas the general Aristotelian view is that perception is an actualization of a passive potency inherent in the soul, Olivi thinks that perception is a /268/ process in which the perceiving subject is active. It is something the subject does, not something he or she undergoes. Olivi claims that this is evident to us also from experience: "Moreover, we experience inwardly within ourselves that those acts [i.e., acts of the powers of our souls] issue from us and that we really perform them." 81

Olivi's criticism of passive theories of perception has to be understood against this background. He thinks that action belongs to the agent, not to the patient. Thus, if perception amounted to being acted upon, the cognitive act would not belong to us but to the object:

Because then understanding, perceiving, and desiring taken actively should be attributed to the objects and not to the powers, just as enlightening and heating are attributed to the sun or to fire rather than to the illuminated air. ${ }^{82}$

Olivi thinks that any activity belongs properly to the agent and not to the

79“Quia a specie corporali situm et extensionem habente non potest produci actus videndi simplex et spiritualis et vivus. Sed species genita in organo ab obiecto est huiusmodi." (II Sent. q. 58, 489)

${ }^{80}$ See II Sent. q. 58, 464-70; ibid., q. 73, 83-97; ibid., 74, 122-4, 130-1. For discussion, see Tachau, Vision and Certitude, 3-26, 39-54; Pasnau, Theories of Cognition, 236-47.

81 "Praeterea, nos intime experimur in nobis actus istos procedere a nobis et quod nos vere operamur illos." (II Sent. q. 58, 463-4. See also ibid., q. 72, 24; ibid., 38; ibid., q. 74, 124.)

82 “Quia tunc intelligere aut sentire vel appetere active accepta potius deberent attribui ipsis obiectis quam ipsis potentiis, sicut et illuminare aut calefacere potius attribuitur soli vel igni quam aeri illuminato." (II Sent. q. 58, 463.) 
recipient, that is, activity belongs to the active party which brings the action about and not to the passive recipient of the action. Thus, his claim amounts to saying that if the act of seeing an apple is caused solely by the apple, we should say that the apple is seeing because it is active in the process of perception. Moreover, he argues that an act receives its essence completely from the agent that produces it; thus there would be no reason to think that only human and non-human animals are capable of cognition if external objects were capable of producing cognitive acts. A perceptual object would in this case, in principle, be capable of bringing about an act of cognition, not only in our cognitive powers but in everything else it happens to act upon. 83

This idea may sound idiosyncratic, and in fact it presupposes the active nature of perception as a premise without proving it. Yet, it shows clearly how strongly Olivi conceives of cognitive acts as activity, not passivity. Our acts of perception cannot be caused by objects just because they are active.

Philosophically, the most interesting line of the critique, however, is based on Olivi's conception of the necessity of paying attention in order to be able to perceive: /269/

Moreover, if the efficient principle of the act is only the species and not our power in any way, [I ask] why it is always necessary for there to be an actual orientation (aspectus) to the object? And why are a kind of virtual stretching out of the power to the object and a kind of strong effort (conatus) of the power to understand, or to perceive, more intensively and efficaciously always necessary ${ }^{84}$

We shall return to this below, but it is important to note that the starting point for Olivi's criticism of the idea that the cognitive acts of the soul are caused by the species is the active nature of sense perception. The soul is depicted as directing itself, reaching out to external objects, and trying to make its perceptions better.

Finally, Olivi does not accept theories of type (c), according to which the cognitive acts of the soul are brought about by species which are caused by the powers of the soul. He rejects this position even though it depicts

\footnotetext{
${ }^{83}$ II Sent. q. 58, 463-6.

84 "Praeterea, si actus non est aliquo modo a potentia nostra tanquam a principio effectivo, sed solum ab ipsis speciebus: ad quid igitur requiritur semper actualis aspectus et quaedam virtualis protensio ipsius potentiae ad obiectum et quidam vehemens conatus ipsius ad intentius et efficacius intelligendum vel sentiendum?" (II Sent. q. 58, 466.) See Perler, Théories de l'intentionnalité, 61-71.
} 
the soul as active. Even if we suppose that the species which are generated by the soul might not veil the external objects from us, there is no reason to suppose that perception takes place by the mediation of species. Olivi's first line of criticism is based on the principle of parsimony: if the powers of the soul are capable of producing a species which then causes a cognitive act, why are these powers not capable of producing a cognitive act in the first place? Moreover, he thinks that in order for the soul to produce a species representing a particular object, it would first have to look at the object. Otherwise there would be no explanation for the similarity between the species that is brought about by the soul and the object which the species should represent. However, looking at the object is already a cognitive act. Thus, even though not all versions of species theory deny the active nature of the soul or lead to epistemological problems, sensible species are still superfluous, according to Olivi. ${ }^{85}$

The same idea is also used to oppose a variation of theory (c) which claims that the powers of the soul must be excited by the objects before they can bring about species. Olivi points out that the only way external objects can excite the powers of the soul is by their similitudes. Understood in this way, there is no difference between theories (c) and (b), and the critique against the latter applies also to the former. Moreover, in order to have any role in the $/ 270 /$ process of perception, the excitative activity of the objects must somehow affect the powers of the soul. Olivi thinks that there are only two options: either the soul perceives the excitation or not. In the latter case the excitation has no role whatsoever, and in the former case we come back to the problems pertaining to theories of type (b). ${ }^{86}$

Olivi's description of the theory of the type (c) does not exactly match with Kilwardby's view. There are no sensible species coming from the object to the sense organs in the first version of (c), and the second version appeals to an idea that Kilwardby explicitly rejects, namely, that the external objects somehow excite the soul to produce species. Nevertheless, there are some affinities between (c) and Kilwardby's idea that the soul causes a species which then brings about the act of the soul. Both seem to fall under Olivi's epistemological criticism:

When a power looks at a species, it either extends its gaze (aspectus) beyond the species and looks at the thing, or it does not extend its gaze. If it does [...] it looks at the object in itself after looking at the species, and so it will see the object in two ways, namely, by the

\footnotetext{
${ }^{85}$ II Sent. q. 58, 473; ibid., q. 74, 122-3.

${ }^{86}$ II Sent. q. 58, 474-7; ibid., q. 72, 26.
} 
species and, in addition to this, in itself without the species. But if it does not extend its gaze, it does not see the object as being present. It sees it only in the same way as we say that we see a thing when we cognize it as absent. ${ }^{87}$

This line of criticism is aimed against the idea that cognitive acts of the soul are caused both by the soul and the external object. Even though there are differences between this idea and Kilwardby's view, it seems that Olivi is in a position to criticize Kilwardby's view.

\section{Criticism of Augustinian Ideas}

Augustine's works contain two general accounts of sense perception, although it remains unclear which of them Augustine favours. The first account is roughly the view which Kilwardby advances: external objects cause bodily changes, the soul apprehends these changes by an active process, and external objects are perceived somehow by apprehending the bodily changes. According to the alternative-the extramissive visual ray theory-the soul sends /271/ forth visual rays which reach external objects and thus enable the soul to perceive them. ${ }^{88}$

Olivi accepts neither of these accounts (although his own view includes elements which are in certain respects reminiscent of visual ray theories). We have seen how Kilwardby makes use of sensible species as carriers of information from external objects to sense organs. Although there are no indications that Olivi is familiar with Kilwardby's theory-at least he never refers to his works explicitly ${ }^{89}$ - he presents arguments against principles which are essential for Kilwardby. In particular, he takes up the Augustinian idea that "sensation is a bodily change that does not go unnoticed by the soul". ${ }^{90}$ He reads this idea in a similar way to that of Kilwardby: an external object causes a bodily change which the soul notices

\footnotetext{
87“Praeterea, quando potentia aspicit speciem, aut ultra eam transit suus aspectus ad aspiciendum rem aut non. Si transit [...] ergo post inspectionem speciei inspiciet obiectum in se ipso, et ita videbit eum duobus modis, scilicet, per speciem et ultra hoc absque specie in se ipso. Si autem non transit, igitur non videt praesentialiter obiectum nisi solum illo modo quo dicimur videre rem, quando eam cogitamus absentem $[\ldots]$ " (II Sent. q. 58, 469.)

${ }^{88}$ For discussion on the history of visual ray theory, see David C. Lindberg, Theories of Vision from al-Kindi to Kepler (Chicago, 1976), 3-67.

${ }^{89}$ Note, however, that Olivi employs the metaphor of active wax which can be found in DSF, although the context is somewhat different. See II Sent. q. 58, 415-6; ibid., 506-7.

90 "sensus est passio corporis per se ipsam non latens animam." (II Sent. q. 58, 484.) Olivi refers to quant. an. 25 and mus. 6.
} 
thus perceiving the object which has caused the change. Olivi makes only a brief comment on this idea, but it is loaded with philosophical acuteness:

Yet this formulation seems to mean that the bodily change (passio corporis) is the object that is perceived [...] Furthermore, "does not go unnoticed by the soul" (non latere animam) means only absence of unnoticing, or it means in addition to this some actual knowledge on the part of the soul. But the former cannot be true, since there cannot be absence of unnoticing when there is no knowledge and since it would then not add anything real to the definition [of perception] [...] But if it means actual knowledge in addition to this, this actual knowledge means the whole essence of an act of perception. Therefore, it adds a complete act of perception to the bodily change, and not just in any way, but in such a way that the bodily change is the object of the act. Therefore, this definition has a vice of contrariety, and in addition to this it has a vice of being nonsense. ${ }^{91}$

/272/ In short, Olivi's idea is that non latere animam may mean either (i) absence of unnoticing without any actual noticing, in which case it means nothing, or (ii) some kind of actual noticing of the bodily change. The first option cannot be true on the grounds that it does not add anything to the definition of perception: there is a bodily change, but the soul does not notice it. And the problem with the second option is that in order to actually notice the bodily change, the soul has to bring about a cognitive act, the object of which is the bodily change. The only way in which the soul can notice the bodily change is by perceiving it. Neither of these options helps to account for a perception of external objects. In other words, Olivi argues that if Augustine (and by consequence, Kilwardby) are correct, we are able to perceive only the bodily changes which external objects cause in our sense organs. It is easy to see how, in Olivi's view, this leads at the very least to problems of representationalism; at the worst it prevents us from seeing even a representation of an external object, for bodily changes are (supposedly) quite different from the objects which cause them.

\footnotetext{
91 “Et tamen in hoc dicto includi videtur quod ipsa passio sit ipsum obiectum quod sentitur [...] Hoc etiam, scilicet, non latere animam, aut dicit solam negationem latentiae aut ultra hoc dicit aliquam actualem notitiam ipsius animae. Primum autem nullo modo stare potest; tum quia negatio latentiae non potest esse ubi nulla est notitia; tum quia tunc nihil reale adderet in definitione [...] Si autem ultra hoc dicit actualem notitiam, sed illa actualis notitia dicit totam essentiam actus sentiendi. Ergo ad passionem additur totus actus sentiendi, et hoc non qualitercunque, sed ut habens ipsam passionem pro obiecto. Ergo haec definitio habet in se vitium contratietatis et ultra hoc vitium nugationis." (II Sent. q. 58, 484. See also ibid., q. 74, 113-4, 123-4.)
} 
Olivi sees an important tension within the Augustinian theories of perception. Corporeal objects are incapable of acting directly on the soul, due to the ontological superiority of the soul. Although they are capable of causing bodily changes, these changes still remain on a lower ontological level, and, as such, they cannot actualize the powers of the soul. The soul needs to notice the bodily changes in order for them to have any effect on it, and Olivi points out that in order for the soul to be able to perceive the bodily changes, it has to be fully capable of cognitive action by itself. It has the ability of cognizing things that are external to it, and it cannot be aided by anything corporeal in its cognitive processes. Olivi's idea is that, Augustine notwithstanding, the ontological superiority of the soul in fact makes bodily changes superfluous. This consequence may seem counter-intuitive, but as we shall see, Olivi is willing to accept it.

Olivi also rejects Augustine's ideas concerning extramission. Extramissive theories of perception were fairly popular in antiquity, but medieval philosophers did not usually regard them as a valid alternative. This attitude was not changed by the fact that Augustine might be taken as a proponent of an extramissive theory. Olivi paraphrases Augustine's position as follows:

[...] on this matter [Augustine] said something that nobody these days follows. One of these things is the idea of corporeal rays proceeding from the eye all the way to the objects. He says that these rays are kinds of bodies-like rods that are emitted from the eyes and invigorated by them [...] He also says that the act of vision takes place in the place where /273/ the object is seen (that is, where the rays are terminated) rather than in the eyes, whence the rays spring forth. ${ }^{92}$

Olivi points out that Augustine did not present a unified theory of perception, 93 and his ideas need not be accepted: "it is not necessary to follow Augustine in this matter." 94 He does not develop a thorough criticism of visual ray theories, but the two central principles that he rejects are presented in the passage above: the idea that there is a real emission of corporeal particles from the eyes to the object, and the ensuing idea that the act

\footnotetext{
92 “[...] in hac materia [Augustinus] quaedam dixit quae nullus hodie sequitur, ut est illud de radiis corporalibus ab oculo usque ad obiecta progredientibus. Quos radios dixit esse quaedam corpora quasi quasdam virgas ab oculis emicantes et ab eis vegetatas [...] Dixit etiam quod actus visionis potius fit in loco ubi est res visa, ubi scilicet terminantur isti radii, quam in loco oculi, unde scilicet erumpunt isti radii." (II Sent. q. 58, 482.)

${ }^{93}$ II Sent. q. 73, 55-6; ibid., q. 74, 113.

94 “... ] in hac parte non est necessarium Augustinum sequi." (II Sent. q. 58, 484.)
} 
of perception takes place in or at the object. Olivi agrees that the powers of the soul must reach the objects somehow, but he denies the emission of particles. Moreover, the perceptual acts of the soul can take place only in the soul, and as the soul can be only in the body (leaving aside separate existence after death), the perceptual acts of the soul can take place only in the body. This is attested to by our experience as well, since we feel that the acts of perception take place in the organs of our bodies and not outside our bodies. ${ }^{95}$

It is noteworthy that Olivi's criticism of visual ray theories pertains only to the physiological and metaphysical aspects of the theories. For, in fact, his own theory incorporates certain psychological aspects of a visual ray theory, as we shall shortly see.

\section{Attention and Intentionality}

Olivi is aware of the originality of the theory of perception which he presents as an alternative to the views he criticizes. ${ }^{96}$ Although some elements of his view are taken from earlier theories, he rejects certain central principles of Aristotelian natural philosophy and revises some of the ideas he takes from Augustine to the extent that they cannot properly be called Augustinian.

The central aspect of Olivi's theory of perception is the attentive nature of the soul. Perception is possible because the soul pays constant attention to the $/ 274 /$ body and to the external world. It has an ability to direct its attention in various "directions" - to various external senses (and through them to the perceptual qualities of external objects), to memories, to things that the subject imagines, to intellectual thoughts, and so forth. When we pay attention to an external object, the soul brings about a cognitive act pertaining to that object, and we perceive it. ${ }^{97}$

Perception requires that our senses somehow reach objects. Olivi accounts for the connection between the soul and external objects by claiming that the powers of the soul are capable of virtually reaching out to objects:

[...] a power can be present to something either essentially or virtually. This is to say that it can be present to something in such a way that its essence is really beside that thing, or in such a way that the

\footnotetext{
${ }^{95}$ See, e.g., II Sent. q. 58, 482-94 passim; ibid., q. 73, 55-69.

${ }^{96}$ II Sent. q. 58, 515.

${ }^{97}$ See, e.g., II Sent. q. 59, 555; ibid., q. 73, 63-4, 89; ibid., q. 74, 130; Petrus Olivi, Quodlibeta quinque, ed. S. Defraia, Collectio Oliviana VII (Grottaferrata, 2002) I.7, 25-6.
} 
orientation (aspectus) of its power is so efficaciously directed to the thing that it, as it were, really touches the thing. If the power is not present to its object or patient in this second way, it cannot act, even if it were present to it by its essence or according to the first way. Visual power is present to a thing that is seen from a distance in this [second] way. [...] This [kind of ] presence suffices for an act of seeing $[\ldots]^{98}$

Although the idea of virtual presence may seem idiosyncratic, Olivi's basic idea is clear. The soul can pay attention to the external world, and by the intentional directing of its cognitive powers to external objects, it is capable of acquiring information from them. Olivi's way of explaining the soul's capacity to reach out to the external objects is in certain ways reminiscent of a visual ray theory. Although he explicitly denies the theory, he incorporates some of its most general intuitions and revises only the metaphysical basis of the view. Thus he takes seriously the idea that perception is something we do, since we have to pay attention in order to perceive, and he thinks that our senses are able to reach external objects directly by intentional directedness towards them. The idea of virtual reaching out is in many ways close to visual ray theories, but it differs from them in the fact that no real emission of corporeal /275/ particles takes place and in the fact that the acts of perception take place in the organs of the senses.

As the perceptual acts of the soul are caused solely by the soul, one might ask why objects are needed in the first place, if the soul is capable of causing its cognitive acts entirely by itself. Olivi thinks that objects are not efficient causes of cognitive acts but that they are necessary for perception. In order to account for the role of the object, he invents a new type of causality, which he calls "terminative causality" (causa terminativa). His idea is that objects function as end-terms of intentional acts of the soul. The acts of the soul are brought about by the soul, but they receive their contents from the objects they pertain to: the acts receive their genus from the power of the soul, but they receive their species from the object. My act of seeing a cat is an act of seeing because it is brought about by my sense of sight, and it is an act of seeing the cat because the cat functions as the

\footnotetext{
98 “[...] virtus aliqua potest esse prasens alicui aut essentialiter aut virtualiter, hoc est dictu, quod potest esse prasens alicui per hoc quod sua essentia est vere iuxta istum aut per hoc quod aspectus sua virtutis ita efficaciter est directus in ipsum acsi realiter attingeret ipsum. Si autem hoc secundo modo virtus non sit prasens suo obiecto vel patienti, non poterit agere, etiamsi per essentiam suam seu iuxta primum modum esset prasens illi. Hoc autem modo virtus visiva est prasens rei visa distanti ab ipsa. [...] hac prasentia sufficiat ad actum videndi [...]" (II Sent. q. 58, 486-7.)
} 
end-term for the act. ${ }^{99}$

According to Olivi, intentionality is a fundamental feature of perception, and it cannot be reduced to other more elementary features. ${ }^{100} \mathrm{Al}-$ though this view is in many ways original and exceptional in the thirteenth century, the idea of intentionality is not entirely without precursors. As we have seen, both Kilwardby and Augustine think that the intentional relation between the soul and the body, i.e., the soul's permanent attention to the body, explains why the soul notices corporeal changes in the sense organs. Although perception of an external object requires a sensible species within the soul, the formation of this species presupposes intentionality. To be sure, Olivi goes further than Kilwardby as he claims that the soul is capable of paying attention directly to external objects through a distance, but both of them take the philosophically crucial step and account for the soul's ability to cross the line between spiritual and corporeal levels by appealing to intentionality.

The idea of the soul's constant attention also answers a problem that has been raised with respect to Olivi's theory. ${ }^{101}$ According to Olivi, an intentional act of perception becomes possible only if the soul pays attention to the object which it perceives. At the outset this idea seems problematic because he does not seem to give any explanation for the initial emergence of the soul's attention towards certain objects instead of others within one's perceptual /276/ field. For instance, if I want to see an apple, I have to pay attention to it. But how am I able to pay attention to the apple? One might claim that I pay attention to the apple because I have seen apples before, and I want to see one anew. However, this answer cannot be applied to my first act of seeing an apple. The attention by which I saw an apple cannot be based on yet another attention because that would lead into infinite regress, and it cannot be caused by the apple, as the soul cannot be acted upon by corporal objects.

In fact, Olivi provides an answer to this problem. We just have to turn to his discussions concerning angelic cognition in order to find it. In question 36 of Summa ${ }^{102}$ he points out that we do not have to intend to perceive a certain object in order to be able to perceive it, for: "we can direct our eyes without having an intention to determinately see those things that are

\footnotetext{
${ }^{99}$ II Sent. 72, 36-7; See also Petrus Ioannis Olivi, 'Epistola ad fratrem R', ed. S. Piron, C. Kilmer \& E. Marmursztejn, Archivum franciscanum historicum 91:1-2 (1998), 13, 55.

${ }^{100}$ Perler, Théories de l'intentionnalité, $43-71$. It has been claimed that Olivi's view is original in thirteenth-century discussions. See, e.g., Perler, Théories de l'intentionnalité, 67 and 71.

${ }^{101}$ Perler, Théories de l'intentionnalité, 71-2.

${ }^{102}$ Written between 1277-9 in Narbonne.
} 
at the time before our eyes."103 Although Olivi speaks only about directing the eyes, the idea applies also to directing one's attention. When we actually remember a certain object and want to see it, we simply open our eyes, pay attention to our visual field, and hope for the best. We can pay attention to the external world without fixing our attention to any definite object, and the objects that happen to be present function as the end-terms of our attention, thus enabling us to perceive them.

Already this idea eases the problem. But Olivi has an even more profound answer. It is based on a possibility of paying attention to the external world without actually perceiving anything:

[...] although the intellect or the power of hearing is directed forcefully to somewhere, nevertheless in the power of hearing remains some unnoticeable (occulta) directedness to the whole hemispherein such a way that if a vehement sound goes off somewhere, the power of hearing perceives it quickly. The power of hearing does not need to be directed to the sound anew because the preceding unnoticeable directedness suffices for perception. [... ] It [viz. the power of hearing] is not directed to something in such a way that there would not remain some kind of general attention (generalis aspectus) to other things that are present or accessible to it. ${ }^{104}$

/277/ Even when we concentrate on thinking about philosophical problems, the soul and its powers pay attention to the external world. This attention is unnoticeable and does not bring about acts of perception, but it enables the acts of our senses. We learn from this text that soul's attention must not be understood as if it were a kind of act. It is more like a permanent state of the soul which enables cognitive activity with respect to the corporeal world. And in this respect, Olivi's view resembles Kilwardby's idea about the constant attention the soul pays to the body.

\footnotetext{
103 “. ...] nos possumus convertere oculos absque hoc quod intenderimus determinate videre illas res quae tunc obiciuntur coram oculis nostris [... ]" (II Sent. 36, 634.)

104 “[... ] licet intellectus vel auditus sint ad aliud fortiter conversi, nihilominus remanet in ipso auditu quedam occulta conversio ad totum emisperium ita quod si ibi fiat vehemens sonus, subito percipit illum, non preeunte aliqua nova conversione auditus ad illum, quia sufficiebat ad hoc predicta conversio occulta. [... ] non est ita conversa ad alia quin remaneat sibi quidam generalis aspectus ad alia sibi presentia vel pervia." (Petrus Ioannis Olivi, 'Quaestio de locutionibus angelorum', ed. S. Piron, Oliviana 1 (2003), §32, http:/ / oliviana.revues.org/document18.html.) Olivi is here dealing with angelic cognition, but he draws from human experience to make his point. For a discussion concerning this text, see Toivanen, Animal Consciousness, 113-6, where I point out that this text is crucial in order to understand Olivi's conception of attention, without, however, relating it to the problem which Perler rises.
} 


\section{Conclusion}

Kilwardby's theory of perception emphasizes the activity of the sensory soul and at the same time it argues for the existence of species in the medium. By positing these, Kilwardby becomes subject to the criticism that Olivi aims against the species doctrine, but Kilwardby's stressing of the fact that what the soul perceives is the object, not the species, seems to soften the critique. However, by upholding the Augustinian idea of the activity of the soul, as making in itself and through itself the images of exterior objects, Kilwardby shares some essential features with Olivi's theory of sense perception. Furthermore, both Kilwardby and Olivi agree that the object is the terminus or the condition sine qua non for perception, that the activity of the soul is motivated by the impossibility of corporeal objects to be the efficient cause of sensory acts, and, finally, both refuse to accept Augustine's extramission theory of visual rays.

Looked at from the point of view of the Aristotelian theory of perception, neither Kilwardby's nor Olivi's views make any sense. There is no match between the Aristotelian picture and the notion that the soul is the sole efficient cause of its perceptual acts, or that there is no real connection between the object seen and the sense power. Nor does the role of the object in the perceptual process conform to Aristotelian views. However, whereas Kilwardby endeavours, as far as possible, to maintain some correspondence with Aristotle, Olivi presents a theory that is clearly nonAristotelian. Moreover, although Olivi's theory is inspired by Augustine's philosophy, he reshapes it to the extent that his theory cannot be labelled Augustinian either. /278/

Kilwardby's and Olivi's common ontological commitments and common source of inspiration lead them to treat perceptual process as an active rather than passive process. However, they differ from each other in their relation to the Augustinian tradition of the activity of the sensitive soul. Whereas Kilwardby endeavours to combine Aristotelian and Augustinian ideas, Olivi rejects both to the extent that he sees it philosophically necessary. Yet there are many similarities in their ideas, and in many respects Olivi's view is better contextualized within the Augustinian tradition of which Kilwardby is an illustrative example. The comparison of these two authors shows that even the same Augustinian undercurrent may yield different kinds of theories. 